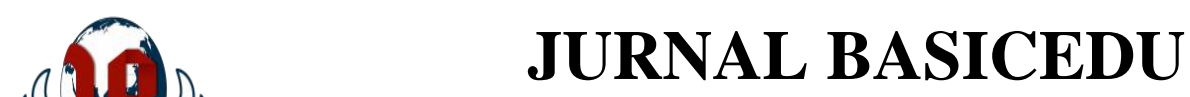

Volume 5 Nomor 4 Tahun 2021 Halaman 1735 - 1742

Research \& Learning in Elementary Education

https://jbasic.org/index.php/basicedu

PAHLAWAN

\title{
Pemanfaatan Alat Peraga Benda Konkret untuk Meningkatkan Motivasi dan Hasil Belajar Matematika di Sekolah Dasar
}

\author{
Kuncoro Adi Saputro ${ }^{1 凶}$, Christina Kartika Sari ${ }^{2}$, SW Winarsi ${ }^{3}$ \\ Universitas Muhammadiyah Surakarta, Indonesia ${ }^{1,2,3}$ \\ Sekolah Dasar Negeri 04 Kemiri, , Indonesia \\ E-mail : kuncoroadi1993@gmail.com ${ }^{1}, \underline{\text { christina.k.sari@ums.ac.id }}{ }^{2}, \underline{\text { swwinarsi@yahoo.com }}^{3}$
}

\begin{abstract}
Abstrak
Penelitian ini di latarbelakangi karena rendahnya motivasi dan hasil belajar siswa pada muatan pembelajaran matematika. Hal tersebut karena pembelajaran selama pandemi yang digunakan guru kelas masih kurang bervariasi serta kurangnya menggunakan media pembelajaran yang menarik. Siswa hanya mengerjakan buku siswa serta kurangnya penjelasan dalam pembelajaran. Akibatnya siswa kurang motivasi dan hasil belajar siswa rendah. Tujuan penelitian ini untuk meningkatkan motivasi dan hasil belajar siswa pada pembelajaran matematika dengan pemanfaatan alat peraga benda konkret. Penelitian ini menggunakan metode penelitian tindakan kelas (PTK) yang dilaksanakan sebanyak dua siklus. Setiap siklus dilaksanakan dalam dua kali pertemuan. Subjek penelitian adalah siswa kelas II SD Negeri 04 Kemiri dengan jumlah 22 siswa. Teknik pengumpulan data yang digunakan adalah observasi, wawancara, dokumentasi, dan tes. Berdasarkan hasil yang diperoleh selama pelaksanaan penelitian tindakan kelas diperoleh hasil yang memuaskan. Pada siklus I rata-rata siswa 71,58 meningkat menjadi 80,33 pada siklus II. Sedangkan dalam peningkatan motivasi belajar siswa pada siklus I rata-rata 3,08 dan pada siklus II menjadi 3,58. Berdasarkan hal tersebut, dapat disimpulkan bahwa pemanfaatan alat peraga benda konkret dapat meningkatkan motivasi dan hasil belajar siswa matematika kelas II SD Negeri 04 Kemiri.
\end{abstract}

Kata Kunci : motivasi belajar, hasil belajar, alat peraga benda konkret, matematika.

\begin{abstract}
This research is motivated by the low motivation and learning outcomes of students on the content of learning mathematics. This is because the learning during the pandemic used by classroom teachers is still less varied and the lack of use of interesting learning media. Students only work on student books and lack of explanation in learning. As a result, students lack motivation and student learning outcomes are low. The purpose of this research is to increase students' motivation and learning outcomes in learning mathematics by using concrete object teaching aids. This study uses classroom action research (CAR) which was carried out in two cycles. Each cycle is carried out in two meetings. The research subjects were second grade students of SD Negeri 04 Kemiri with a total of 22 students. Data collection techniques used are observation, interviews, documentation, and tests. Based on the results obtained during the implementation of classroom action research, satisfactory results were obtained. In the first cycle, the average student was 71.58 and increased to 80.33 in the second cycle. Meanwhile, in increasing student motivation in the first cycle the average was 3.08 and in the second cycle it was 3.58. Based on this, it can be concluded that the use of concrete object teaching aids can increase the motivation and learning outcomes of second grade mathematics students at SD Negeri 04 Kemiri.
\end{abstract}

Keywords: learning motivation, learning outcomes, teaching aids concrete objects, mathematics.

Copyright (c) 2021 Kuncoro Adi Saputro, Christina Kartika Sari, SW Winarsi

Corresponding author:

Email : kuncoroadi1993@gmail.com

DOI : : https://doi.org/10.31004/basicedu.v5i4.992

ISSN 2580-3735 (Media Cetak)

ISSN 2580-1147 (Media Online) 
1736 Pemanfaatan Alat Peraga Benda Konkret untuk Meningkatkan Motivasi dan Hasil Belajar Matematika di Sekolah Dasar - Kuncoro Adi Saputro, Christina Kartika Sari, SW Winarsi

DOI: https://doi.org/10.31004/basicedu.v5i4.992

\section{PENDAHULUAN}

Matematika merupakan materi pembelajaran yang sering ditakuti oleh peserta didik. Menurut peserta didik matematika adalah pembelajaran yang sulit, harus menggunakan rumus-rumus, guru jarang menggunakan media pembelajaran sebagai alat untuk mempermudah siswa dalam belajar matematika sehingga motivasi matematika siswa rendah. Hal ini sependapat dengan penelitian yang dilakukan (Sulistyaningsih, 2012) mengungkapkan bahwa pada umumnya kemampuan peserta didik dalam koneksi matematika masih rendah. Rendahnya kemampuan koneksi matematika peserta didik akan mempengaruhi kualitas belajar peserta didik yang berdampak pada rendahnya prestasi peserta didik dan motivasi belajar. Menurut (Hudoyono, 1979) mengatakan bahwa hakikat matematika berkenaan dengan ide-ide, strukturstruktur dan hubungan-hubungan yang diatur menurut urutan yang logis. Sehingga bisa dikatakan matematika adalah ilmu pasti dengan jawaban yang pasti yang menggunakan rumus-rumus bukan dengan penalaran.

Belajar adalah suatu proses yang ditandai dengan adanya perubahan pada diri seseorang. Perubahan sebagai hasil dari proses belajar dapat ditunjukan dalam berbagai bentuk, seperti perubahan pengetahuan, pemahaman, tingkah laku, ketrampilan, kebiasaan, serta perubahan aspek-aspek yang ada pada diri individu yang sedang belajar. Kegiatan dan usaha untuk mencapai perubahan tingkah laku merupakan proses belajar, sedangkan perubahan tingkah laku itu sendiri merupakan hasil belajar. Dengan demikian, belajar akan menyangkut proses belajar dan hasil belajar. Menurut (Kunandar, 2013) hasil belajar adalah kompetensi atau kemampuan tertentu baik kognitif, afektif maupun psikomotorik yang dicapai atau dikuasai peserta didik setelah mengikuti proses belajar mengajar. Menurut (Sanjaya, 2014) belajar adalah berbuat untuk memperoleh pengalaman tertentu sesuai dengan tujuan yang diharapkan. Hasil belajar dipengaruhi oleh pengalaman subjek belajar dengan dunia fisik dan lingkungannya. Hasil belajar siswa tergantung pada apa yang telah diketahuinya, subjek belajar, tujuan, motivasi yang mengetahui proses interaksi dengan bahan yang sedang dipelajari. Menurut (Sadirman, 2014) hasil belajar berupa perubahan perilaku atau tingkah laku seseorang yang belajar akan berubah atau bertambah perilakunya, baik yang berupa pengetahuan, keterampilan atau penguasaan nilai-nilai (sikap) menurut para ahli psikologi tidak semua perubahan tingkah laku dapat digolongkan ke dalam hasil belajar. Hasil belajar yaitu "perubahan-perubahan yang terjadi pada diri siswa, baik yang menyangkut aspek kognitif, afektif, dan psikomotor sebagai hasil dari kegiatan belajar" (Susanto, 2013).

Agar hasil belajar maksimal seorang siswa harus mempunyai motivasi belajar. Menurut (Djamarah, 2011) motivasi belajar adalah dorongan yang dilakukan individu untuk mengubah energi dalam diri seseorang ke dalam bentuk aktivitas nyata untuk mencapai tujuan. Perubahan energi dalam diri seseorang itu berbentuk suatu aktivitas nyata berupa fisik. Karena seseorang mempunyai tujuan tertentu dari aktifitasnya, maka seseorang mempunyai motivasi yang kuat untuk mencapai dengan segala upaya yang dapat dia lakukan untuk mencapainya. Menurut (Sadirman, 2014) mengatakan bahwa motivasi belajar adalah dorongan dalam kegiatan beajar, sehingga motivasi dapat dikatakan sebagai keseluruhan daya penggerak di dalam diri siswa yang menimbulkan, menjamin kelangsungan dan memberikan arah kegiatan belajar, sehingga diharapkan tujuan dapat tercapai. Motivasi dapat juga dikatakan serangkaian usaha untuk menyediakan kondisi-kondisi tertentu, sehingga seseorang mau dan ingin melakukan sesuatu, dan bila ia tidak suka, maka akan berusaha untuk mengelakkan perasaan tidak suka itu. Jadi motivasi itu dapat dirangsang oleh faktor dari luar tetapi motivasi itu adalah tumbuh di dalam diri seseorang. Dalam kegiatan belajar, motivasi dapat dikatakan sebagai keseluruhan daya penggerak di dalam diri siswa yang menimbulkan kegiatan belajar dan memberikan arah pada kegiatan belajar, sehingga tujuan yang diinginkan dapat tercapai.

Tinggi rendahnya motivasi belajar siswa dapat dilihat ketika proses pelaksanaan pembelajaran seperti, minat siswa ketika belajar, antusias siswa mengikuti pembelajaran, keseriusan siswa ketika guru menjelaskan (Ansori, M., dan Denica H., 2010). Motivasi belajar yang dimiliki siswa dalam setiap kegiatan pembelajaran 
1737 Pemanfaatan Alat Peraga Benda Konkret untuk Meningkatkan Motivasi dan Hasil Belajar Matematika di Sekolah Dasar - Kuncoro Adi Saputro, Christina Kartika Sari, SW Winarsi

DOI: https://doi.org/10.31004/basicedu.v5i4.992

sangat berperan untuk meningkatkan prestasi belajar siswa dalam mata pelajaran tertentu (Nashar, 2004). (A.M, 2006) mengemukakan bahwa motivasi belajar adalah keseluruhan daya penggerak di dalam diri siswa yang menimbulkan kegiatan belajar, yang menjamin kelangsungan dari kegiatan belajar dan memberi arah pada kegiatan belajar sehingga subjek belajar dapat tercapai. Menurut (Hamzah B. Uno, 2009) indikator motivasi belajar meliputi; 1) Adanya hasrat dan keinginan berhasil, 2) Adanya dorongan dan kebutuhan dalam belajar, 3) Adanya harapan dan cita-cita masa depan, 4) Adanya penghargaan dalam belajar, 5) Adanya kegiatan yang menarik dalam belajar, 6) Adanya lingkungan belajar yang kondusif sehingga memungkinkan seseorang siswa dapat belajar lebih baik.

Berdasarkan hasil refleksi peneliti sebagai guru, mempertimbangkan hasil belajar siswa yang kurang maksimal, maka permasalahan ini dianggap penting dan perlu dicari jalan keluarnya. Peneliti mengadakan perbaikan-perbaikan pembelajaran matematika dengan media konkret untuk meningkatkan hasil belajar siswa kelas II Sekolah Dasar Negeri 04. Masalah umum penelitian ini adalah,"Apakah dengan media konkret mampu meningkatkan motivasi dan hasil belajar dalam pembelajaran matematika kelas II Sekolah Dasar Negeri 04 Kemiri?" Untuk memfokuskan penelitian ini peneliti menjabarkan masalah umum menjadi submasalah, (1) Apakah penggunaan alat peraga benda konkret dapat meningkatkan motivasi belajar matematika di Sekolah Dasar? (2) Apakah Penggunaan alat peraga benda konkret dapat meningkatkan hasil belajar matematika di Sekolah Dasar?

Menurut Briggs dalam (Nasution, 2004) berpendapat bahwa harus ada suatu untuk mengkomunikasikan materi (pesan kurikuler) supaya terjadi proses belajar. Karena itu dia mendifinisikan alat peraga sebagai alat peraga sebagai; "wahana fisik yang mengandung materi pembelajaran". Terlepas dari ragamnya pengertian tentang alat peraga, jelaslah bagi kita bahwa alat peraga sebagai alat bantu dalam pembelajaran memiliki fungsi yang jelas, yaitu: memperjelas, memudahkan siswa dalam memahami konsep/prinsip atau teori, dan membuat pesan kurikulum yang akan disampaikan kepada siswa menarik, sehingga motivasi belajar siswa meningkat dan proses belajar dapat lebih efektif dan efesien.

Menurut (Sudjana, 2009), penggunaan benda konkret/nyata didalam proses belajar mengajar terutama bertujuan untuk memperkenalkan suatu unit pelajaran tertentu, proses kerja suatu objek studi tertentu atau bagian-bagian serta aspek-aspek lain yang diperlukan. Benda konkret itu sendiri termasuk media pembelajaran yang berasal dari benda-benda nyata yang banyak dikenal oleh siswa dan mudah didapatkan. Media ini mudah digunakan oleh guru dan siswa karena media ini sering dijumpai di lingkungan sekitar. Prinsip kemudahan ini sesuai dengan kriteria media pembelajaran yang baik. Media konkret merupakan pengalaman yang diperoleh melalui aktifitas sendiri pada situasi yang sebenarnya. Bisa juga sebagai pengalaman langsung yaitu merupakan proses belajar yang sangat bermanfaat, sebab dengan mengalami secara langsung kemungkinan kesalahan persepsi akan dapat dihindari dan siswa juga memperoleh pengalaman secara mudah, menurut (Sanjaya, 2014). Pengalaman langsung dengan menggunakan media konkret juga sangat mempengaruhi hasil belajar siswa dan memiliki ketepatan yang tinggi. Dengan benda konkret akan sangat membantu siswa agar mendekati keadaan yang sebenarnya.

Beberapa penelitian menunjukkan peningkatan motivasi dan hasil belajar dengan menggunakan media konkret. Diantaranya oleh (Parinem, 2014), hasil penelitian ini menunjukkan peningkatan hasil belajar siswa. Peningkatan nilai rata-rata hasil belajar siswa pada Pra Siklus hanya sebesar 60,45. Nilai itu meningkat menjadi sebesar 72,73 pada Siklus I, dan meningkat lagi pada Siklus II menjadi 92,73. Peningkatan nilai ratarata ini diikuti juga dengan peningkatan prosentase pencapaian KKM. Sebelum pelaksanaan siklus perbaikan (Pra Siklus) siswa yang tuntas hanya 4 (36\%) siswa, setelah perbaikan Siklus I meningkat menjadi 7 (64\%) siswa dan pada siklus terakhir yaitu siklus II jumlah siswa yang tuntas meningkat menjadi 11(100\%).

Berdasarkan permasalahan observasi pada SD Negeri 4 Kemiri, dapat diasumsikan bahwa pembelajaran yang dilakukan belum maksimal. Perlu adanya perbaikan pembelajaran yang tepat untuk meningkatkan 
1738 Pemanfaatan Alat Peraga Benda Konkret untuk Meningkatkan Motivasi dan Hasil Belajar Matematika di Sekolah Dasar - Kuncoro Adi Saputro, Christina Kartika Sari, SW Winarsi

DOI: https://doi.org/10.31004/basicedu.v5i4.992

motivasi dan hasil belajar siswa. Solusi untuk meningkatkan masalah tersebut yaitu dengan menggunakan media konkret.

\section{METODE PENELITIAN}

Peneliti dalam melaksanakan penelitian termasuk jenis penelitian tindakan kelas. Jenis penelitian ini adalah penelitian tindakan kelas. (Mulyasa, 2013) penelitian tindakan kelas merupakan upaya untuk mencermati kegiatan belajar kelompok peserta didik dengan memberikan tindakan yang dimunculkan guru bersama-sama antara guru dengan peserta didik dibawah bimbingan guru yang bertujuan memperbaiki dan meningkatkan kualitas pembelajaran. Menurut (Rubiyanto, 2011) penelitian tindakan kelas adalah suatu pencermatan terhadap kegiatan pembelajaran, berupa tindakan yang sengaja dimunculkan dan terjadi dalam sebuah kelas. Kemudian pendapat berbeda mengungkapkan, PTK merupakan kegiatan untuk mengamati kejadian dalam pembelajaran di kelas guna memperbaiki hasil belajar menjadi lebih baik dalam proses pembelajaran ungkap Bahri pada (Hartono, 2009). Pelaksanaan penelitian ini dilakukan dengan beberapa siklus, serta dengan menggunakan model spiral sesuai dengan yang dikemukakan oleh Kemmis dan Targat dalam (Hendawati, Y. and Kurniati, 2017) yang terdiri dari perencanaan, observasi \& tindakan serta refleksi. Prosedur pada setiap siklus saling berkesinambungan.

\section{Bagan Model Spiral Oleh Kemmis dan Targgat}

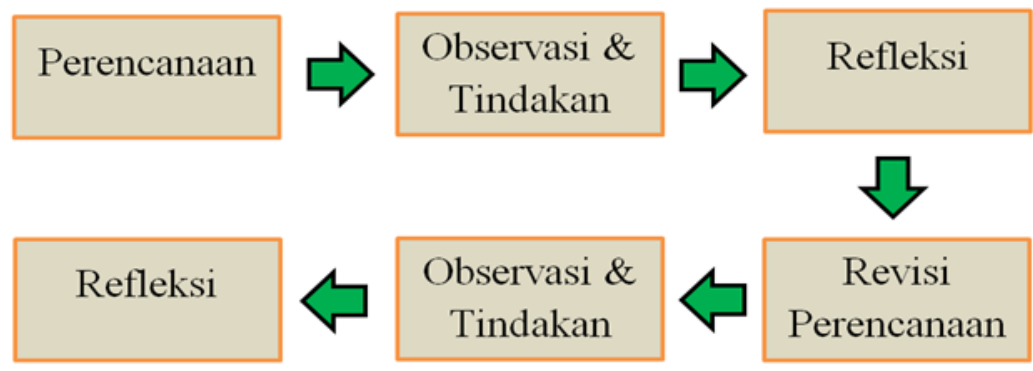

Pelaksanaan penelitian di SD Negeri 4 Kemiri semester 2 tahun ajaran 2020/2021. SD Negeri 4 Kemiri merupakan SD yang terletak di dusun Dawung, Kecamatan Kebakkramat, Kabupaten Karanganyar. Kemudian subjek penelitian ini merupakan siswa kelas II SD Negeri 4 Kemiri berjumlah 22 siswa. Pelaksanaan penelitian ini bekerjasama dengan guru kelas II SD Negeri 4 Kemiri yaitu Ibu Sugiyanti, S.Pd.SD dalam melaksanakan penelitian ini.

Penelitian saat pengumpulan data pelaksanaannya menggunakan teknik tes dan observasi. Tes dipergunakan untuk mengetahui sejauh mana keberhasilan proses pembelajaran pada akhir kegiatan dengan memberikan soal-soal tes tertulis untuk mengukur hasil belajar peserta didik pada ranah kognitif. Dalam mengunakan tehnik observasi cara yang efektif adalah melengkapi dengan format atau blangko pengamat sebagai instrumen.

\section{HASIL DAN PEMBAHASAN}

Berdasarkan hasil penelitian diperoleh rata-rata presentase motivasi belajar siswa dalam penggunaan alat peraga pada siklus I dan siklus II dapat dilihat pada tabel dibawah ini : 
1739 Pemanfaatan Alat Peraga Benda Konkret untuk Meningkatkan Motivasi dan Hasil Belajar Matematika di Sekolah Dasar - Kuncoro Adi Saputro, Christina Kartika Sari, SW Winarsi

DOI: https://doi.org/10.31004/basicedu.v5i4.992

Tabel 1. Presentase Motivasi Belajar Siswa pada Siklus 1 dan Siklus 2

\begin{tabular}{|c|l|c|c|c|c|}
\hline \multirow{2}{*}{ No. } & \multicolumn{1}{|c|}{ Indikator } & \multicolumn{2}{|c|}{ Siklus } & Peningkatan & Prosentase \\
\cline { 3 - 4 } 1. & $\begin{array}{l}\text { Adanya hasrat dan keinginan } \\
\text { berhasil }\end{array}$ & 3,03 & 3,65 & 0,62 & $20 \%$ \\
\hline 2. & $\begin{array}{l}\text { Adanya dorongan dan kebutuhan } \\
\text { dalam belajar }\end{array}$ & 3,12 & 3,52 & 0,4 & $12 \%$ \\
\hline 3. & $\begin{array}{l}\text { Adanya minat dan perhatian siswa } \\
\text { terhadap pelajaran }\end{array}$ & 3,02 & 3,64 & 0,62 & $20 \%$ \\
\hline 4. & $\begin{array}{l}\text { Adanya semangat siswa untuk } \\
\text { melakukan tugas-tugas belajarnya }\end{array}$ & 3,15 & 3,54 & 0,39 & $12 \%$ \\
\hline & Jumlah & 12,32 & 14,35 & & \\
\hline & Rata-rata & 3,08 & 3,58 & & \\
\hline
\end{tabular}

Pembahasan motivasi belajar siswa saat proses pembelajaran pada siklus I dan siklus II tiap-tiap indikatornya sebagai berikut: a) Adanya hasrat dan keinginan berhasil. Sebagian siswa belum mempunyai hasrat dan keinginan berhasil. Untuk meningkatkan hasrat dan keinginan berhasil siswa dalam belajar dengan menambah inovasi dalam pembelajaran dan dorongan semangat untuk siswa. Berdasarkan hal tersebut kriteria peningkatan sangat baik dengan angka sebanyak 20\%. b) Adanya dorongan dan kebutuhan dalam belajar. Sebagian siswa belum mempunyai dorongan dan kebutuhan dalam belajar. Untuk meningkatkan semangat siswa dalam belajar dengan memberikan dorongan semangat untuk siswa. Berdasarkan hal tersebut kriteria peningkatan sangat baik dengan angka sebanyak 12\%. c) Adanya minat dan perhatian siswa terhadap pelajaran. Sebagian siswa belum memiliki minat dan perhatian terhadap pelajaran. Untuk meningkatkan minat dan perhatian siswa terhadap pelajaran dilakukan dengan menggunakan media konkret. Berdasarkan hal tersebut kriteria peningkatan sangat baik dengan angka sebanyak 20\%. d) Adanya semangat siswa untuk melakukan tugas-tugas belajarnya sebagian siswa belum mempunyai semangat untuk melakukan tugastugasnya. Cara untuk membantu siswa adalah dengan cara membimbing siswa dalam setiap pembelajaran dan menjelaskan materi pelajaran dengan sejelas mungkin. Berdasarkan hal tersebut kriteria peningkatan sangat baik dengan angka sebanyak $12 \%$.

Hasil data penelitian diuraikan berdasarkan siklus-siklus tindakan pembelajaran. Hasil data tersebut disesuaikan dengan masalah penelitian mencakup data perencanaan, dan proses pembelajaran. Data tentang perencanaan adalah persiapan pengajaran tertulis yang berupa satuan pelajaran. Data proses pembelajaran meliputi tahap sebelum menulis, saat menulis, dan setelah menulis. Hasil data ini didasarkan pada data yang telah dikumpulkan melalui pengamatan dan catatan lapangan ketika pembelajaran berlangsung.

Tabel 2. Hasil Belajar Pada Siklus 1 dan 2

\begin{tabular}{|c|l|c|c|l|}
\hline No & \multicolumn{1}{|c|}{ Komponen Analisis } & $\begin{array}{c}\text { Siklus } \\
\text { I }\end{array}$ & $\begin{array}{c}\text { Siklus } \\
\text { II }\end{array}$ & Keterangan \\
\hline 1. & Tuntas Belajar & $47 \%$ & $81 \%$ & $34 \%$ (meningkat) \\
\hline 2. & Belum Tuntas Belajar & $53 \%$ & $19 \%$ & $34 \%$ (menurun) \\
\hline 3. & Rata-rata & 71,58 & 80,33 & $12 \%$ (meningkat) \\
\hline
\end{tabular}

Pada siklus I, dengan menerapkan penggunaan alat peraga pada materi pelajaran diperoleh nilai rata-rata hasil belajar siswa adalah dan ketuntasan belajar mencapai $47 \%$. Hasil tersebut menunjukkan bahwa pada 
1740 Pemanfaatan Alat Peraga Benda Konkret untuk Meningkatkan Motivasi dan Hasil Belajar Matematika di Sekolah Dasar - Kuncoro Adi Saputro, Christina Kartika Sari, SW Winarsi

DOI: https://doi.org/10.31004/basicedu.v5i4.992

siklus pertama secara klasikal siswa belum tuntas belajar, karena siswa yang memperoleh nilai $>74$ hanya sebesar $47 \%$ lebih kecil dari persentase ketuntasan yang dikehendaki yaitu sebesar $70 \%$.

Pelaksanaan pembelajaran pada siklus pertama ini masih banyak yang perlu diperbaiki, akan tetapi ada beberapa hal yang tetap digunakan pada siklus kedua yaitu penggunaan alat peraga hanya sedikit di tambahkan gambar-gambar yang berkaitan dengan materi. Karena selama ini hanya siswa yang pandai saja yang menjawab pertanyaan guru sedangkan siswa lainnya masih pasif dan menunggu jawaban dari guru saja. Pada siklus II, diperoleh nilai rata-rata hasil belajar siswa adalah 80,33 dan ketuntasan belajar sudah mencapai $81 \%$. Hasil ini menunjukkan bahwa sudah mencapai target yang dikehendaki yaitu $>70 \%$ pada siklus II ini.

Adanya peningkatan hasil belajar siswa ini karena siswa merasa terbantu dan senang dengan penggunaan alat peraga yang diberikan oleh guru. Penggunaan alat peraga dalam penyampaian materi besar pengaruhnya terhadap hasil belajar siswa. Siswa terlihat bersemangat dalam pembelajaran di kelas dan sesuatu hal yang baru untuk mereka dan siswa dapat menjawab pertanyaan guru dengan baik.

Belajar menggunakan alat peraga membuat siswa bisa lebih memahami materi pengukuran secara jelas, serta siswa berani mengemukakan pendapatnya dan juga menanggapi pendapat orang lain. Siswa juga terlatih untuk dapat berpikir kritis dan saling tenggang rasa. Siswa juga dilibatkan untuk lebih bertanggung jawab baik secara individu maupun kelompok.

Motivasi siswa pun terus meningkat dari rasa bosan untuk belajar matematika karena siswa belajar dengan menggunakan media perantara dalam pembelajaran. Hal ini seperti yang kemukakan oleh menurut (Azhar Arsyad, 2011) media pembelajaran adalah segala sesuatu yang dapat digunakan untuk menyampaikan pesan atau informasi dalam proses belajar mengajar sehingga merangsang minat belajar dan motivasi siswa. (Rusman, 2016) mengungkapkan bahwa penggunaan media pembelajaran yang sesuai dengan karakteristik kebutuhan siswa dan materi yang hendak disampaikan, akan turut membangkitkan rasa ingin tahu, motivasi, konsentrasi dan hasil belajar serta sebagai stimulus dalam kegiatan pembelajaran .Siswa sudah tidak menganggap matematika adalah pelajaran yang sulit tetapi adalah pelajaran yang mudah jika dikerjakan menggunakan media apapun. Adapun perbaikan yang akan diterapkan pada siklus II adalah dengan menciptakan suasana pembelajaran yang santai dan menyenangkan. Guru menjelaskan ulang tahapan penggunaan alat peraga dengan menambah waktu pada tiap-tiap tahap dan lebih detail menjelaskan tahapantahapannya. Pada siklus II siswa lebih tertantang untuk mengerjakan soal yang diberikan guru dengan rasa senang dan semangat. Peneliti sebagai pengamat dibantu oleh mitra kolaborasi mengamati aspek-aspek kegiatan yang dilakukan oleh guru dan siswa.

Sebagian siswa telah mampu meningkatkan hasil belajar dengan ketuntasan belajar sesuai dengan kriteria nilai KKM yaitu 74. Ada perbedaan antara tes sebelum dilakukan penggunaan alat peraga dan sesudah proses belajar mengajar dengan menggunakan alat peraga. Melalui alat peraga siswa dapat belajar dengan senang dan tertangtang untuk mengerjakan dengan benar dan lebih termotivasi lagi untuk ingin tahu pada pelajaran yang diberikan dan alat peraga apa yang akan digunakan. Jika suasana belajar dicipatakan semenarik mungkin dengan alat peraga yang lebih menarik lagi, maka motivasi belajar siswa akan muncul dan terus bertambah. Dengan demikian kegiatan belajar akan berjalan dengan baik.

Metode pembelajaran menggunakan alat peraga dapat membuat siswa lebih semangat dan aktif dalam pembelajaran. Peran aktif siswa terlihat dari kontribusi pendapat dan kesungguhan mereka dalam bekerja sama selama diskusi dalam mengerjakan tugas yang diberikan oleh guru. Motivasi belajar siswa mengalami peningkatan terjadi pada siklus II, dengan kata lain penggunaan alat peraga untuk pembelajaran ini mengajak siswa untuk lebih aktif dan kreatif dalam proses pembelajaran matematika. Hal ini seperti yang di ungkapkan oleh Sudjana, alat peraga adalah suatu alat yang dapat diserap oleh mata dan telinga dengan tujuan membantu guru agar proses belajar mengajar sisa lebih efektif dan efisien.

Berdasarkan hal tersebut pembelajaran dengan menggunakan alat peraga dapat meningkatkan hasil belajar siswa pada materi pengukuran untuk siswa kelas II di SD Negeri 04 Kemiri. Hal ini dapat dilihat dari 
1741 Pemanfaatan Alat Peraga Benda Konkret untuk Meningkatkan Motivasi dan Hasil Belajar Matematika di Sekolah Dasar - Kuncoro Adi Saputro, Christina Kartika Sari, SW Winarsi

DOI: https://doi.org/10.31004/basicedu.v5i4.992

rata-rata nilai tes siswa setelah diterapkan dengan menggunakan alat peraga mengalami peningkatan di setiap siklusnya, demikian juga dengan banyaknya siswa yang telah memenuhi KKM >74 dan mengalami peningkatan pada setiap siklusnya.

\section{KESIMPULAN}

Berdasarkan hasil penelitian yang telah di lakukan penggunaan alat peraga dapat meningkatkan motivasi dan hasil belajar siswa pada mata pelajaran Matematika di SD Negeri 04 Kemiri Kecamatan Kebakkramat Kabupaten Karanganyar. Penerapan penggunaan alat peraga membuat siswa lebih aktif dan lebih mudah memahami materi pelajaran dengan baik. Peningkatan hasil belajar tersebut ditandai dengan meningkatnya dari siklus 1 ke siklus 2. Peningkatan prosentase ketuntasan hasil belajar siswa di tandai ketuntasan pada siklus I mencapai angka 47\% siswa pada siklus 1 dan pada siklus 2 mencapai angka $81 \%$ siswa sudah mencapai KKM > 74 dari jumlah keseluruhan 22 siswa. Peningkatan motivasi belajar di tandai dengan meningkatnya motivasi belajar siswa pada setiap pertemuan dan pada setiap siklus yaitu di siklus pertama 3,08 dan siklus 2 menjadi 3,58 .

\section{UCAPAN TERIMAKASIH}

Penulis dalam menyusun penelitian ini mengucapkan puji syukur kepada Allah SWT atas limpahan rahmat dan hidayah dalam menyusun penelitian ini. Peneliti mengucapkan kepada orang tua, beserta keluarga yang telah memberikan dukungan secara moral dan materiil. Terimakasih kepada Bapak/Ibu Dosen Pendidikan Profesi Guru Universitas Muhammadiyah Surakarta dan teman-teman PPL serta guru dan staf SD Negeri 04 Kemiri yang telah memberikan bimbingan dan arahannya. Semoga penelitian yang disusun dapat bermanfaat bagi semua. Serta pihak yang telah memberikan dukungan dalam peneliti.

\section{DAFTAR PUSTAKA}

A.M, S. (2006) Interaksi dan Motivasi Belajar-Mengajar. Jakarta : PT Raja Grafindo Persada.

Ansori, M., dan Denica H., N. (2010) Pengaruh Keputusan Investasi Keputusan Pendanaan dan Kebijakan Dividen Terhadap Nilai Perusahaan Pada Perusahaan Yang Tergabung Dalam Jakarta Islamic Index Studi Pada Bursa Efek Indonesia ( BEI ). Analisis Manajemen. ISSN: 1411 -1799, 4 (2).

Azhar Arsyad (2011) Media Pembelajaran. Jakarta : PT Raja Grafindo Persada.

Djamarah, S. B. (2011) Psikologi Belajar. Jakarta : Rineka Cipta.

Hamzah B. Uno (2009) Teori Motivasi dan Pengukurannya Analisis di Bidang.

Hartono (2009) 'Langkah-langkah Penelitian Tindakan Kelas', pp. 1-24.

Hendawati, Y. and Kurniati, C. (2017) 'Penerapan Metode Eksperimen Terhadap Pemahaman Konsep Siswa Kelas V Pada Materi Gaya Dan Pemanfatannya', Metodik Didaktik, 13(1). doi: 10.17509/md.v13i1.7689.

Hudoyono, H. (1979) Pengembangan Kurikulum Matematika Dan Pelaksanaannya Didepan Kelas. Surabaya: Usaha Nasional.

Kunandar (2013) Penilaian Autentik (Penilaian Hasil Belajar Peserta Didik Berdasarkan Kurikulum 2013). Jakarta : PT. Rajagrafindo Persada.

Mulyasa (2013) Pengembangan dan Implementasi Kurikulum 2013. Bandung: Rosda.

Nashar (2004) Peranan Motivasi dan Kemampuan Awal dalam Kegiatan Pembelajaran. Jakarta: Delia Press.

Nasution, N. (2004) Pendidikan Matematika di Sekolah Dasar. Jakarta: Universitas Terbuka. 
1742 Pemanfaatan Alat Peraga Benda Konkret untuk Meningkatkan Motivasi dan Hasil Belajar Matematika di Sekolah Dasar - Kuncoro Adi Saputro, Christina Kartika Sari, SW Winarsi

DOI: https://doi.org/10.31004/basicedu.v5i4.992

Parinem (2014) 'Peningkatan Hasil Belajar Siswa Menggunakan Media Konkret Dalam Pembelajaran Matematika Kelas V Sekolah Dasar', Angewandte Chemie International Edition, 6(11), 951-952.

Rubiyanto, R. (2011) Metode Penelitian Pendidikan. Surakarta:FKIP PGSD UMS.

Rusman (2016) Model-model pembelajaran: mengembangkan profesionalisme Guru. Jakarta: Rajawali Pers.

Sadirman (2014) Interaksi dan Motivasi Belajar mengajar. Jakarta: PT Raja Grafindo Persada.

Sanjaya, W. (2014) Strategi Pembelajaran Berorientasi Standar Proses Pendidikan. Jakarta: Kencana Prenadamedia Group.

Sudjana, N. (2009) Dasar-dasar Proses Belajar Mengajar. Bandung : Sinar Baru Algensido.

Sulistyaningsih, D. dkk. (2012) Model Pembelajaran Kooperatif Tipe CIRC dengan Pendekatan Konstruktivisme untuk Meningkatkan Kemampuan Koneksi Matematik. Unnes Journal of Mathematics Education Research. Vol. 1. No.2. Halaman: 126.

Susanto, A. (2013) Teori Belajar \& Pembelajaran di Sekolah Dasar. Jakarta: Kencana Prenadamedia Group. 